This is the peer reviewed version of the following article: (2010) Journal of Law and Society Vol. 37(4), 569-591, which has been published in final form at $d x . d o i . o r g / 10.1111 / j .1467-6478.2010 .00522 . x$. This article may be used for non-commercial purposes in accordance with Wiley Terms and Conditions for

Self-Archiving.

The Compensation Culture: Cliché or Cause for Concern?

\author{
James Hand \\ BA (Hons), PgDL, PgDip, LLM, FHEA \\ Associate Senior Lecturer \\ School of Law, \\ University of Portsmouth, \\ Richmond Building, \\ Portland Street, \\ Portsmouth \\ PO1 3DE \\ Email: James.Hand@port.ac.uk
}

\begin{abstract}
The 'compensation culture' has featured frequently in the UK popular press over the last decade. There have, however, been comparatively few academic studies and such studies as there have been have largely focussed on personal injury claims. A compensation culture, if it exists, could extend much wider than that. This article compares the exponential increase in the use of the term 'compensation culture' in the national printed media since 1995 with available statistics relating to the Queen's Bench, County Courts and Employment Tribunals. Far from spiralling upwards, these statistics show a broad decline across a range of claims with the exception of claims before the Employment Tribunals, where the government has created a slew of new heads of claim. In order to counter the misconceptions founded by the popular media, and to allow for greater scrutiny, more attention should be paid to the collection and dissemination of judicial and claims statistics.
\end{abstract}

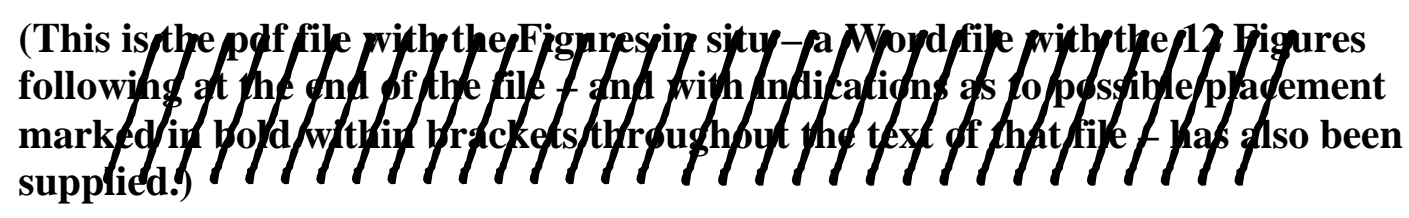

This is the accepted version (post peer review) this article. It is made available here with due acknowledgement to the Journal of Law and Society, Cardiff University Law School and Blackwell Publishing. The article appears at (2010) Journal of Law and Society Vol. 37(4), 569591 and the definitive online version is available at wileyonlinelibrary.com (http://onlinelibrary.wiley.com/doi/10.1111/j.1467-6478.2010.00522.x/pdf). 


\title{
The Compensation Culture: Cliché or Cause for Concern?
}

\author{
James Hand*
}

\section{Introduction}

The 'compensation culture' and comments about the increasing slide towards American litigiousness frequently appear in the media. Stories about people suing after injuring themselves with, for example, cups of coffee, through using recreational facilities, or by consuming tobacco or fast food, and articles decrying the removal of hanging baskets and playground slides evidently make for good copy; national newspaper articles concerning the compensation culture have increased exponentially since the mid 1990s. ${ }^{1}$ Peysner considers such media clamour to be a hindrance to a sensible debate on seeking redress, with much of the media hype spuriously making the importation of a US-style compensation crisis into an apparent law of nature. ${ }^{2} \mathrm{~A}$ further hindrance has been the lack of academic scrutiny, but there is now an emerging

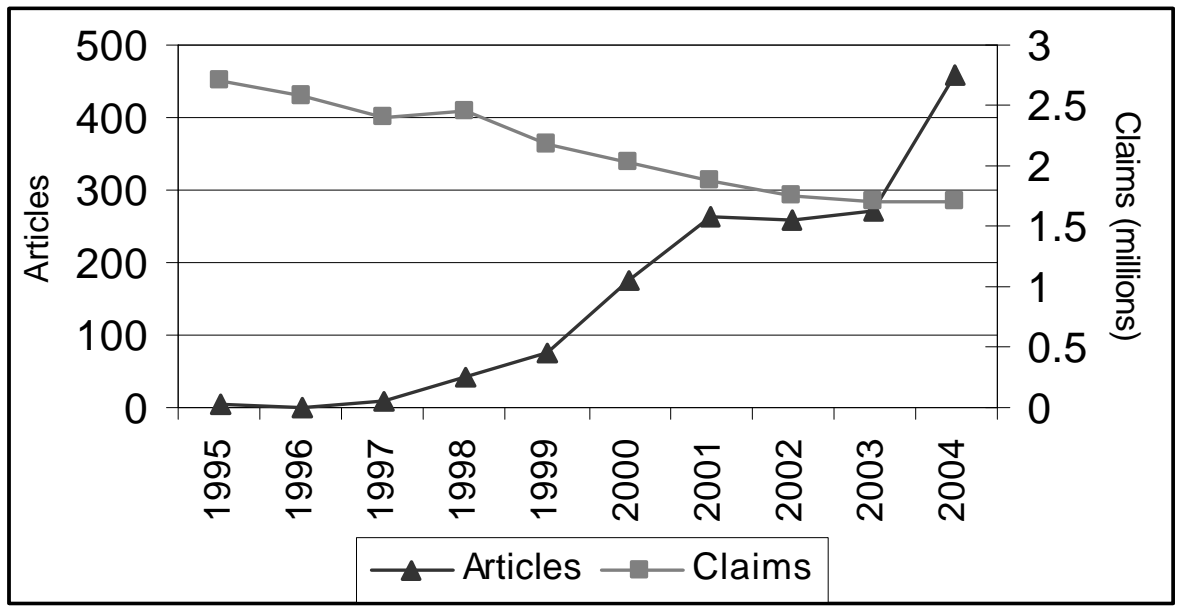

Figure 1 - Compensation Culture: : Claims v Articles (claims are for the Queen's Bench, County Courts and Employment Tribunals; articles are articles in national newspapers)

\footnotetext{
* School of Law, University of Portsmouth, Richmond Building, Portland Street, Portsmouth PO1 3DE, England james.hand@port.ac.uk

I should like to thank Vivien Pickford, Roger Welch, Damian Carney and the anonymous referees for their guidance and comments on earlier drafts. Any errors are my own.

${ }^{1}$ From three times, two times and seven times, in 1995 / $96 / 97$, to highs of 259, 269 and 459 times in 2002, 2003, 2004. The number of mentions has fallen since then but it is still much higher than in the late 1990s; there were 134 mentions in 2006 and 2007 and 111 in 2008 (LexisNexis UK National Newspapers search 'compensation culture' 01/1/xx - 31/12/xx).

2 J. Peysner, 'Compensation crazy - too much claim and blame?' The Times 28 May 2002. Such fears fail to take into account that UK legal and social systems are very different from those of the US. Indeed, Kritzer's study found that the differences between the US and England were cultural as well as legal: "the stereotypical images of the stoic English person and the complaining American are more than just stereotypes" (H.M. Kritzer, 'Propensity to Sue in England and the United States of America: Blaming and Claiming in Tort Cases' (1991) 18 Journal of Law and Society 400). He went on to agree with Atiyah's dismissal, in 'Tort Law and the Alternatives: Some Anglo-American Comparison' (1987) Duke Law J. 1002, of contingency fees as an explanation for Anglo-American differences, not least because contingency fees are also forbidden in Australia where the claiming pattern does not resemble the English one but is much closer to that of the US (at 426).
} 
literature on the topic. ${ }^{3}$ This literature, while recognising that the compensation culture could be defined more widely, tends to focus on personal injury claims. This article seeks to take a broader look at available statistics, but first considers the background to the newspaper coverage of the compensation culture.

\section{Media Coverage of the Compensation Culture}

The phrase 'compensation culture' first appeared in UK national newspapers in the mid-1990s. " As Morris points out, the "compensation culture' is an amorphous term" and can be applied to a range of claims, including personal injury, employment and Human Rights Act claims, and to specific aspects within them (such as the amount of damages awarded, the propensity to sue, an explosion in the number of claims, and the expanding categories within tort law). ${ }^{5}$ Williams further adds family law disputes, litigation risks associated with some commercial activities, and concerns over lawyers' excessive fees and the drumming up of trade. ${ }^{6}$ With regard to the latter, it was the introduction of conditional fee agreements in the mid-to-late $1990 \mathrm{~s}^{7}$ which heralded the advent of the ubiquitous television adverts by claims management companies, such as the infamously defunct Claims Direct - subsequently taken over by Russell, Jones and Walker - and The Accident Group (and such current firms as The National Accident Helpline and AccidentLawyers4u). These adverts set out to encourage people to 'have-a-go' which in turn fuels a media portrayal of easy apparent windfalls, greedy claimants and grasping lawyers. ${ }^{8}$ Such coverage would seem to threaten replacing the maxims de minimis non curat lex and Winfield's de minimis non agit sapiens ${ }^{9}$ with 'where there's blame, there's a claim'.

The "host of bads" that are said to accompany an excess of law - such as high insurance, inefficiency, fragmentation, homogenisation and the decline of community, dignity, spontaneity and self-reliance - together with the amount of coverage in the papers mean that politicians have been keen to address the issue, compounding the

\footnotetext{
${ }^{3}$ See, e.g., K. Williams, 'State of Fear: Britain's “'Compensation Culture', Reviewed' (2005) 25 Legal Studies 499; R. Lewis, A. Morris \& K. Oliphant, 'Tort personal injury claims statistics: is there a compensation culture in the United Kingdom?' (2006) 30 Journal of Personal Injury Law 87; A. Morris, 'Spiralling or Stabilising? The Compensation Culture and Our Propensity to Claim Damages for Personal Injury' (2007) 70(3) MLR 349-378; Better Regulation Task Force, Better Routes to Redress. (2004) London: Cabinet Office Publications.

${ }^{4}$ A Lexis Library search reveals the earliest mention to be 17 December 1993 in a feature in The Times written by Bernard Levin ('Addicted to welfare').

${ }^{5}$ Morris, op. cit., n.3, pp 350, 363.

${ }^{6}$ Williams, op.cit., n.3, pp 500-501.

${ }^{7}$ These allowed for a, more restricted, success fee as opposed to the US contingency fee whereby lawyers take a percentage of the award; the first CFAs appeared in 1995 (created by the Conditional Fee Agreements Order 1995 (SI 1995/1674) under s.58 of the Courts and Legal Services Act 1990) but the system wherein the loser pays the winner's lawyers' success fee dates to the Access to Justice Act 1999. ${ }^{8}$ A report compiled for the Department of Constitutional Affairs shows that "Advertising, and in particular TV advertising, seems clearly to be the main source of awareness when it comes to personalinjury compensation" and that readers of tabloid newspapers are more likely to believe that there is a culture of falsely claiming compensation than those who do not regularly read a tabloid (C. Edwards and L. Holme, 'Report on quantitative and qualitative research conducted for the Department for Constitutional Affairs' (March 2006) Millward Brown, pp.15 and 17.

${ }^{9}$ W.V.H Rogers, Winfield and Jolowicz on Tort, 15th ed. (London, Sweet \& Maxwell, 1998) 65. Loosely translated as the wise man does not act over trifling things. There appears to be no space for Winfield's version of the aphorism in the more recent edition of the eponymous text.
} 
coverage in the press. ${ }^{10}$ Stephen Byers has spoken out about the growing threat to public services caused by the culture of "blame, claim and gain", while Boris Johnson has lamented that even school rugby is under threat, with the number of private schools offering the sport having fallen $30 \%$ over a fifteen year period. ${ }^{11}$ David Davis, in an impassioned article in the Spectator in which he called for wide reform (including 'cutting the cancer of litigation out of the public services', 'sunsetting health and safety legislation' and reforming discrimination laws), gave six examples of the 'rights' culture in a 144-word paragraph. ${ }^{12}$ However, it is significant to note that his favourite case, that of the "Australian conman who exposed intimate details of the Prime Minister's family affairs and then claimed that deportation from Britain would infringe his 'right to respect for private and family life"', was actually dismissed in court. As Almond points out in relation to regulatory myths, the media have an interest in the amusing and political nature of such stories and, even if the full details are given at first, through "a process of secondary reproduction and repetition [such cases] become well-known and acquire significance, a process which gives the story a life almost independent from the circumstances of the original case", but which may serve a political interest. ${ }^{13}$

\section{'Exploding the Urban Myth'}

Following this increase in media coverage, the Better Regulation Task Force (BRTF) reviewed the area of redress. Their 2004 report, Better Routes to Redress, was foreworded with the subheading "Compensation Culture: Exploding the Urban Myth". ${ }^{14}$ They found that the compensation culture did not, in fact, exist but noted that the mere perception of a compensation culture causes problems. Taking on the various definitions of the compensation culture, the report stated that the number of accident claims, the claims most commonly featured in the media, were actually going down $;{ }^{15}$ that the majority of payments were very small; ${ }^{16}$ and that tort costs as a percentage of GDP are under one-third of those in the US and lower than in many European countries. ${ }^{17}$

The fear of litigation can have some positive effects (e.g. improved risk assessments, maintenance and services), but too great a fear - and the encouragement of misconceived or trivial claims - can cost the taxpayer millions of pounds, clog up the system for those with serious claims and cause people to be over cautious (e.g.,

\footnotetext{
${ }^{10}$ For more on the 'host of bads' see M. Galanter, 'Law Abounding: Legalisation Around the North Atlantic' (1992) 55 Modern Law Review 1, at 1.

11 'Parents will have to foot bill if they sue schools' The Times, 22 March 2004, 7; B. Johnson, 'Knock some sense into the children' Daily Telegraph, 7 August 2003, 18.

12 D. Davis, 'Victim nation' The Spectator, 21 August 2004, 16.

${ }^{13}$ P. Almond, 'The dangers of hanging baskets: 'Regulatory Myths' and Media Representations of Health and Safety Regulation (2009) 36 Journal of Law and Society 352 at p. 356. Or as Haltom and McCann put it, in the context of the more rabid US tort reform debate, the underlying facts become "truncated tales and polemical jeremiads": W. Haltom and M. J. McCann, 'Distorting the Law: Politics, Media, and the Litigation Crisis (2004) Chicago: University of Chicago Press at p.147-148.

${ }^{14}$ Better Regulation Task Force, Better Routes to Redress. (2004) London: Cabinet Office Publications at p.3

15 ibid. at p. 11

${ }^{16}$ ibid. at p.14; e.g. in 2002, $38.8 \%$ of County Court claims were for under $£ 1,000$ and $55 \%$ were for under $£ 3,000$

${ }^{17}$ ibid. at p.15; between 1989 and 2000 UK tort costs amounted to $0.6 \%$ of GDP (save for 1993 when it was $0.7 \%$ ) against a fluctuating figure of between $2.28 \%$ and $1.88 \%$.
} 
impede innovation in the pharmaceutical industry, cause doctors to practice defensive medicine, and lead schools to cut school trips and to ban writing lines as a punishment). ${ }^{18}$ The dissemination of urban myths, trivialising of cases and reporting of claims without mention of the outcome can thus have seriously injurious effects. ${ }^{19}$ The BRTF report picks out the McDonald's coffee case, often quoted as the archetypal compensation culture case, and a cause of the warnings on coffee cups, to exemplify media exaggeration. ${ }^{20}$ While Mrs Liebeck was partially at fault, in the way she tried to add cream to her coffee while a passenger in a stationary car, the coffee was served at $88^{\circ} \mathrm{C}\left(23^{\circ} \mathrm{C}\right.$ above the lowest temperature that would cause serious burns), there had been 700 previous complaints, and McDonalds had decided not to warn customers despite recognising that many would not recognise the danger. The spillage left the seventy-nine year old Mrs Liebeck hospitalised for eight days and disabled for two years. It was in the light of this blatant disregard that its coffee was not fit for consumption that McDonalds (having refused to pay her medical expenses of $\$ 10,000$ ) ended up having to pay damages of $\$ 640,000, \$ 480,000$ of which were punitive (this was down from the jury award of $\$ 200,000$ compensatory and the oft-quoted $\$ 2.7$ million punitive). Punitive damages, they go on to point out, are much more a feature of the US legal system than that of the UK.

It should also be pointed out that in an English case where thirty-six claimants had been burnt by spilt McDonald's beverages (but where the evidence of the temperature was less certain and the claimants' principal witness was much criticised) ${ }^{21}$ the claim was dismissed; that Messrs Tomlinson and Rhind ${ }^{22}$ failed in their respective claims for injuries caused by recklessly diving into a lake and a disused gravel pit respectively; that Mrs Martin, who purportedly broke her ankle by tripping over a pot-hole in a footpath, failed to prove her claim not least because the degradation at the edges of the path did not render it dangerous, ${ }^{23}$ that Mrs McTear failed in her late husband's claim

\footnotetext{
${ }^{18}$ For defensive medicine see e.g. P. Kennedy, 'Is This The Way We Want To Go' (2005) 29 Journal of Personal Injury Law, 117 at 126 and Davis, op. cit., n.12. With regard to school trips, see e.g. A. L. Blair, 'Common sense culture not compensation culture' Speech on Compensation Culture given at University College London on 26 May 2005 http://www.number10.gov.uk/output/Page7562.asp ("In England in 2003 there were between 7 and 10 million pupil visits on school trips. Sadly, there was one fatality. But only one.") and Davis, op. cit. n.12 and NASUWT Press Release 'NASUWT reaffirms advice to members to avoid taking school trips'

<http://www.teachersunion.org.uk/Templates/Internal.asp?NodeID=70431> accessed: 16 July 2005. With regard to the punishment of writing lines, an investigation reported that out of 50 state, private and grammar schools contacted only two still allowed lines to be given out and that in one case, Repton School, the deputy head had been advised that "setting lines was illegal under laws designed to protect children from degrading punishments" ('I Must Not Make Pupils Write Lines..It's Degrading' Mail on Sunday, 10 July 2005, 45).

${ }^{19}$ The Health and Safety Executive are seeking to combat some of these myths and have been running a 'myth of the month' series on their website since April 2007 (http://www.hse.gov.uk/myth/index.htm) as well as rebutting stories as they occur. For more on regulatory myths see P. Almond, op. cit. n.13.

${ }^{20}$ Better Regulation Task Force op. cit. n. 14 at p.13; this was the same case that led Haltom and McCann to write their key work on the misrepresentation of cases in the US media (op. cit. n.13 at ix).

${ }^{21}$ Bogle and others $v$ McDonald's Restaurants Ltd [2002] EWHC 490 (QB); Field J "found both Mr Hathaway and Mr Brazier [for McDonalds] to be truthful and reliable witnesses" (at 26) whereas he was "bound to say I did not find Mr Ives an impressive witness" (at 25), see also , e.g., paras. 19-25, 39 \& 51.

${ }^{22}$ Tomlinson v Congleton BC [2003] UKHL 47; [2004] 1 AC 46; Rhind v Astbury Water Park Ltd [2004] EWCA Civ 756

${ }^{23}$ Martin (formerly Collier) v Peterborough City Council [2003] EWHC 2925
} 
in negligence against Imperial Tobacco in the Scottish courts; ${ }^{24}$ and that, despite world-wide coverage to the contrary, hanging-baskets continue to hang from lampposts in Bury St. Edmunds and elsewhere. ${ }^{25}$

The government welcomed the task force's report and subsequently announced a bill in the May 2005 Queen's Speech which went some way to meet - or even exceed some of the recommendations. ${ }^{26}$ The Compensation Act 2006 not only regulates claims management companies (going beyond the proposed self-regulation) but also purports to clarify the existing common law on negligence so as to reassure people "that there is no liability for untoward incidents that could not be avoided by taking reasonable care". ${ }^{27}$ It seeks to do this through section 1 which states that courts should:

in determining whether the defendant should have taken particular steps to meet a standard of care (whether by taking precautions against a risk or otherwise), have regard to whether a requirement to take those steps might(a) prevent a desirable activity from being undertaken at all, to a particular extent or in a particular way, or (b) discourage persons from undertaking functions in connection with a desirable activity.

This does little more than codify the existing common law $^{28}$ but section 2 does add that apologies, offers of treatment or other redress shall not amount to an admission and thus strengthens alternatives to litigation. ${ }^{29}$

The year of the BRTF report - heading into the 2005 general election - saw the largest number of national newspaper articles referring to the compensation culture and the numbers of articles for the years 2006-2008 are under a third of that level, lower than in 2000 but still substantially higher than in the late 1990s. While section 1 of the Compensation Act 2006 is unlikely to be responsible for the decline, the regulation of claims management companies may have had some effect - the regulatory regime is said to have "had a significant effect in reducing malpractice less than one year after

\footnotetext{
${ }^{24}$ McTear v Imperial Tobacco Ltd Times, June 14, 2005; Lord Nimmo Smith held that she had failed to establish breach of duty and causation in relation to her husband's lung cancer.

${ }^{25}$ the lampposts having been checked for metal fatigue and neoprene collars fitted (St. Edmundsbury Borough Council, 'Bury St Edmunds Will Be Blooming Beautiful Again This Summer' < http://www.stedmundsbury.gov.uk/sebc/new/BURY-ST-EDMUNDS-WILL-BE-BLOOMINGBEAUTIFUL-AGAIN-THISSUMMER.cfm> Accessed: 16 July 2005. The story of hanging baskets being banned from lamp-posts is, as mentioned above, an oft-cited example of the ridiculed 'compensation culture'. See also Almond, op. cit., n.13., at pp.355 - 356. While there have been 'hanging basket' stories involving other councils, Bury would appear to the first.

${ }^{26}$ Department for Constitutional Affairs, 'Tackling the "Compensation Culture"" (November 2004).

${ }^{27}$ Blair, op. cit., n.18.

${ }^{28}$ e.g. the judgment in Tomlinson $v$ Congleton $B C$ n. 21 ; it is interesting to note that only a few months before this the Home Office refused to support a change in legislation regarding intruders insisting new guidelines would be sufficient to clarify the law (see, e.g., http://news.bbc.co.uk/1/hi/uk_politics/4224473.stm and the debate surrounding the passage of Patrick Mercer's Householder Protection Bill).

${ }^{29}$ The NHS Redress Act 2006 has similar aims and was announced in the same Queen's Speech but does not explicitly follow on from the BRTF report. The Act paves the way for an alternative to litigation, aiming to provide quicker redress for low value clinical negligence cases, including investigations, apologies and, if appropriate, financial redress thereby reducing costs to the NHS and to claimants. However, the provision (s.1) enabling the Secretary of State to set up such a scheme by regulations is, some four years on, not yet even in force.
} 
the Compensation Act 2006 received Royal Assent". ${ }^{30}$ While the numbers of stories may have reduced to an extent in recent years, there are still over 100 a year and past stories remain in the collective memory. As the BRTF report stated it is the perception that can cause problems. To what extent if any do the underlying statistics support the perception?

\section{The Statistical Background}

A compensation culture, in which people are more likely to 'blame and claim' or 'have-a-go' rather than display a reasonable level of stoicism, would lead to an increase in claims (though not necessarily successful ones). Such an increase is not borne out by the BRTF report, nor by the study by Lewis, Morris and Oliphant which drew on three main sources - the Compensation Recovery Unit of the Department of Work and Pensions, the Insurers' Bodily Injury Award Studies and NHS statistics. ${ }^{31}$ While it is true that the current level of personal injury claims is much higher than that reported by the Pearson Commission for 1973, the increase occurred some two decades ago rather than as part of a recent phenomenon. Indeed, Lewis, Morris and Oliphant, writing in 2006, found among other things that:

there is no evidence that the tort system has been flooded with an increasing number of personal injury claims in recent years. In fact the number of claims has been relatively stable since at least 1997-1998, the first year for which reliable CRU statistics are available. ${ }^{32}$

They cite the total number of claims notified to the CRU between 2000-2005 as having "increased only by three per cent" (at p.89). While updating the CRU figures to $2009 / 2010$ does show a marked increase on $2000 / 2001$, this is more than due to a sustained increase in motor-related claims (up 68\% since 2000/2001) rather than increases in employer, medical, public liability or other claims. ${ }^{33}$ Indeed, Lord Phillips of Worth Matravers in his evidence in December 2005 to the Constitutional Affairs Committee when asked about the existence of a compensation culture stated:

If you take out of the equation claims for road traffic accident injuries, which are probably not influenced by any kind of culture, then the drop is

\footnotetext{
${ }^{30}$ Ministry of Justice 'Claims management regulation - Impact of Regulation - Initial Assessment (August 2007).

${ }^{31}$ BRTF, op. cit. n.3 at p.11; Lewis, Morris \& Oliphant, op. cit. n.3.

${ }^{32}$ Lewis, Morris \& Oliphant, op. cit. n.3 at 102. The occasional spike in claims relates directly to disease claims and the effect of the British Coal respiratory and hand-arm vibration syndrome claims under the DTI's Chronic Obstructive Pulmonary Disease (COPD) Scheme and the Vibration White Finger (VWF) scheme respectively.

${ }^{33}$ There appear to be two sets of CRU figures, the ones above are from the same set as those used by Lewis, Morris \& Oliphant, op. cit. n.3, Morris, op. cit. n.3, and in Jackson L.J., 'Review of Civil Litigation Costs: Preliminary Report' (May 2009) London: The Stationery Office, Ch. 6 para 4.3 <http://www.judiciary.gov.uk/aboutjudiciary/cost-review/jan2010/voll-low.pdf> [Accessed July 2, 2010] and as published on the CRU website (http://www.dwp.gov.uk/other-specialists/compensationrecovery-unit/performance-and-statistics/). The figures in Appendix 25 to Jackson L.J.'s Preliminary Report covering 2005/06 to 2008/09 and sourced from the CRU show very different figures across the types of claim from those quoted in the report (for 2006/07 and 2007/08) - and from those which appear in the above sources - with differences being up to +/- tens of thousands. However, the general picture is similar with claims being broadly stable or reducing apart from the motor-related claims which again see an increase albeit at a slightly lower rate (21\% for $2005 / 06-2008 / 09$ as opposed to $36 \%)$.
} 
very much more substantial: employer's liability $20 \%$, clinical negligence $34 \%$, and I think the statistics for claims by patients in hospitals who have suffered an untoward event in the course of their treatment suggest that less than $1 \%$ of such patients bring a claim against the hospital, so it does not look like a compensation culture. ${ }^{34}$

However, all of these analyses relate solely to personal injury. If there is a culture of compensation, it could, as noted above, extend far wider than that. The figures from the Compensation Recovery Unit, NHS and Insurance bodies, as used by Lewis, Morris and Oliphant, provide greater depth than figures derived from courts but do not provide as much breadth, as they relate primarily to personal injury. When one looks at the total number of claims started in the Queen's Bench, County Courts and Employment Tribunals over the ten years 1995-2004, a decline is again evident as seen in Figure 1 above, contrasting claims and articles, but this deserves closer analysis. $^{35}$ (The figures stop at 2004 as they include data drawn from Social Trends, which stopped publishing reliable data on the Queen's Bench and County Court after 2004; the problems with the statistics and an analysis of more recent figures are discussed further below.)

\section{The Broader Picture}

Expanding the time frame to twenty years (Figure 2) shows that the figures for the last five of those years are well below the level in the mid 1980s, although there was a steep rise at the turn of the 1990s caused, in part, by the deregulation of lending leading "to more cases concerned with the recovery and collection of debt". ${ }^{36}$ Indeed,

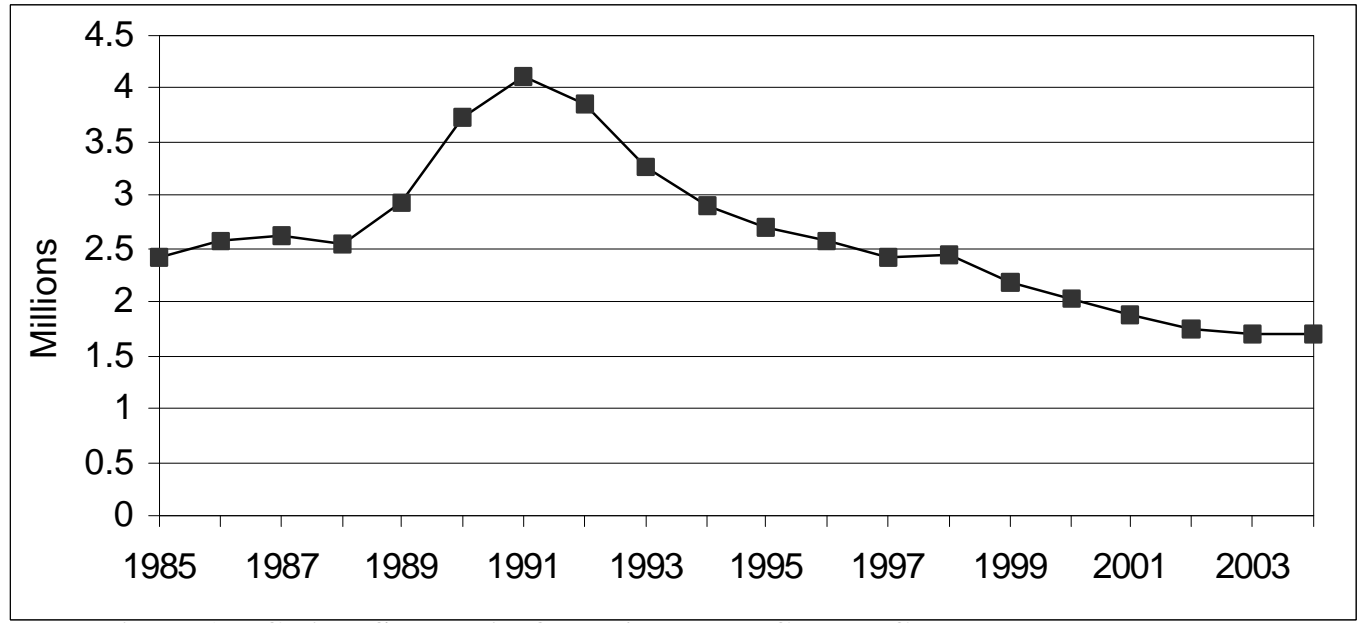

Figure 2 - Claims Started in Queen's Bench, County Court and Employment Tribunals 1985-2004

\footnotetext{
${ }^{34}$ Constitutional Affairs Committee 'Compensation Culture' (Third Report of Session 2005-2006 HC 754, vol. 2); see also references en passant in H. Teff, 'Personal injury: Righting mental harms' (2009) New Law Journal 159.7384 (1243) ("Recent statistical data on the incidence of personal injury claims in general point to relative stability since 1997-8 (Compensation Recovery Unit figures for 2000-8), despite the marked growth in advertising and "no-win no-fee" arrangements) and in M. Lyons 'Jackson - an initial response' (2010) 34 Journal of Personal Injury Law, 74 at 78 (where the current President of the Association of Personal Injury lawyers wrote "Compensation Recovery Unit figures show that broadly over the past 10 years the volume of cases has remained stable").

${ }^{35}$ Furthermore, tort costs as a percentage of GDP would be expected to increase whereas they remained relatively constant between 1989 and 2000 see fn 13.
} 
the figures for the County Courts are below the 1981 level - which was just short of two million claims - and the gap increases when the Queen's Bench figures are included (the 2003 and 2004 figures being over half a million lower than those of 1981). ${ }^{37}$

Breaking the figures down into the component courts and employment tribunal shows that proceedings started in the Queen's Bench have tumbled and county court claims are following a similar, though more sedate, downward pattern whereas employment tribunals, although vacillating, are showing an upward trend (Figure 3). The extent of the decline in Queen's Bench proceedings can be attributed to the jurisdiction change of $1^{\text {st }}$ July 1991 (which allowed county courts to deal with all contract, tort and recovery of land cases regardless of value $)^{38}$ and the bar, introduced in April 1999, on starting proceedings in the High Court where the value of the claim is less than $£ 15,000$. ${ }^{39}$ Despite the former having "shunted an enormous amount of civil litigation" 40 on to the county courts - and the latter contributing to successive year-onyear decreases for 1999 and 2000 of $37.4 \%$ and $62.5 \%$ in proceedings issued in the Queen's Bench - the county courts have nevertheless shown a declining trend.

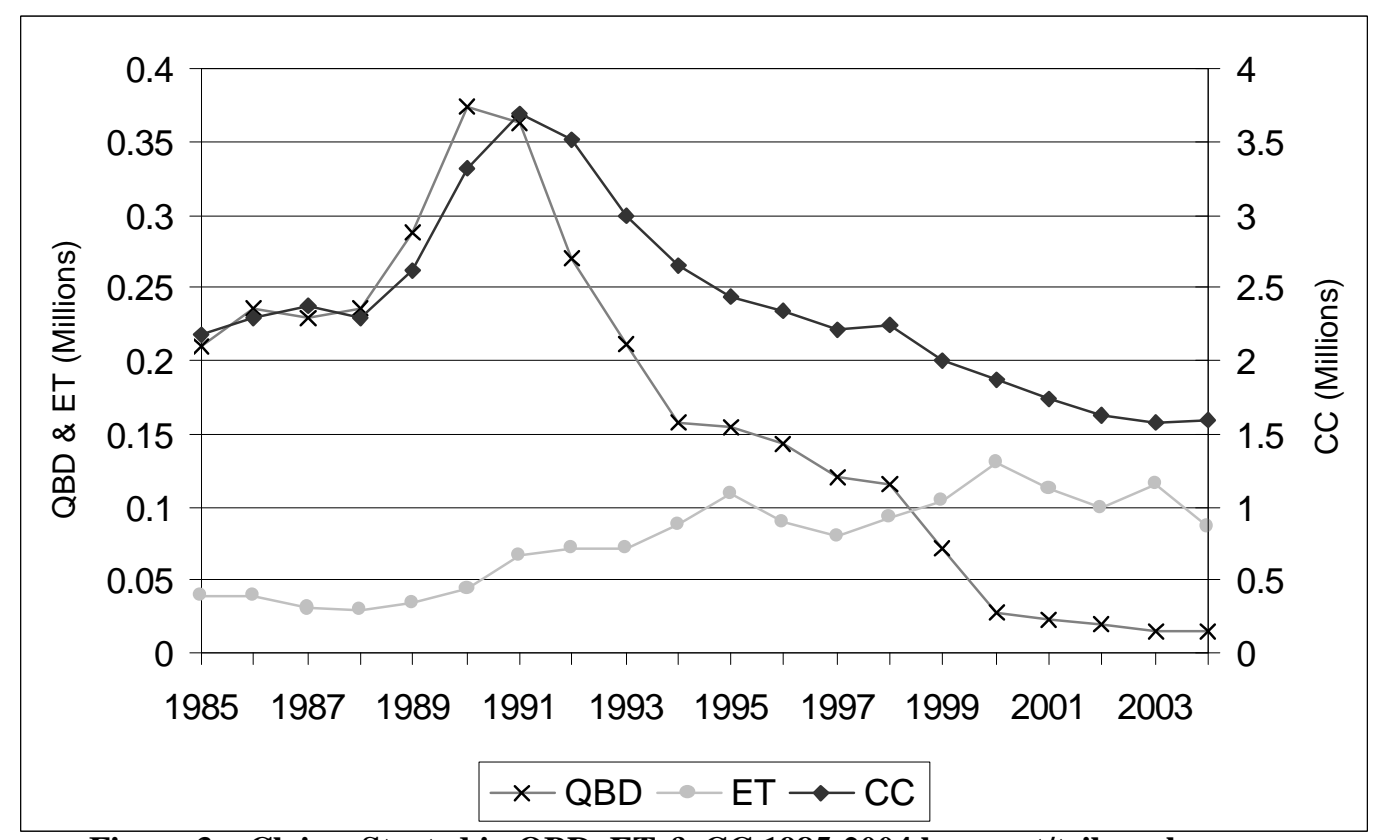

Figure 3 - Claims Started in QBD, ET \& CC 1985-2004 by court/tribunal

This trend can, to some extent, be attributed to the introduction of the Woolf reforms. In Further Findings: A continuing evaluation of the Civil Justice Reforms, the drop in county court claims for contract and tort for the two-year periods before and after the

\footnotetext{
${ }^{36}$ J. Matheson \& C. Summerfield (eds), Social Trends 30 - 2000 edition. (2000, London: Office for National Statistics) 162-163.

${ }^{37} 1981$ Claims issued: County Court 1.996m Queen's Bench $0.183 \mathrm{~m}$ total $2.179 \mathrm{~m}$ Source: National Statistics (http://www.nationalstatistics.gov.uk/STATBASE/xsdataset.asp?vlnk=502); Industrial Tribunal figures going beyond 1985 are not available (a point noted by S. Burgess, C. Propper \& D. Wilson 'Explaining The Growth In The Number Of Applications To Industrial Tribunals, 1972-1997' (2001, DTI Employment Relations Research Series No.10), 13.

${ }^{38}$ The High Court and County Courts Jurisdiction Order 1991 (SI 1991/724)

${ }^{39}$ by the High Court and County Courts Jurisdiction (Amendment) Order 1999 (SI 1999 No 1014), in force from April 261999.

${ }^{40}$ N. Armstrong, 'The litigation myth' (1997) New Law Journal 147.6801 (1058).
} 
introduction of the reforms (April 1999) was compared with the drop in possession of goods and land recovery claims over the same period, the latter being part of the second phase of the reforms (which took effect in October 2001). ${ }^{41}$ That the former claims fell by some $20 \%$ whereas the latter fell by under $1 \%$ shows, it was suggested, that the reforms had a direct effect on the volume of claims. ${ }^{42}$ One should bear in mind, however, that there was a peak of claims before the introduction of the Civil Procedure Rules ${ }^{43}$ and that this may have affected the comparison as the time period included the run-up to stage two of the reforms; and also that such different claims do not necessarily normally reflect each other.

While the "well established" 44 downward trend since April 1999 appears on these figures to have hit a plateau over the last two years shown in the chart (which coincides with the high point of 'compensation culture' stories), claims are, nevertheless, still much lower than they were. How can it be argued that there is a compensation culture in the light of these statistics? Firstly, "quoting statistics will not win the argument whilst the papers run 'compensation culture' stories"; 4 and secondly proponents claim that there are more claims but that they do not reach the courts as they are settled before then. ${ }^{46}$ There is an inherent difficulty in collecting statistics for private settlements, as opposed to settlements during hearing or those brought to court for approval. Slapper notes that there "has not been any precipitous fall in clientsolicitor consultations" despite the fall in claims and suggests this points to out-ofcourt legal vindication ${ }^{47}$ whereas Furedi declares that most "litigious activity" takes place through Alternative Dispute Resolution, out-of-court action and quasi legal arenas and points to the Centre for Effective Dispute Resolution (CEDR) reporting a $106 \%$ increase in mediations in the year to April $1998 .{ }^{48}$ It should, however, be pointed out that in 2003, CEDR reported an all time high of 631 cases - a substantial figure in itself but still less than the post-CPR Queen's Bench and a mere fraction of the cases heard by the county courts. ${ }^{49}$ In any case, an increase in settlements out of court is testament to the Woolf reforms' aim of avoiding litigation where possible, not least through the auspices of pre-action protocols, ${ }^{50}$ provided the parties are not being effectively blackmailed into settling. Moreover, as Morris makes clear, it is erroneous to state that there is no data on settled claims, as Furedi implies, as the Compensation Recovery Unit of the Department of Work and Pensions - on which the BRTF and some of the Lewis, Morris and Oliphant figures are based - records data relating to all

\footnotetext{
${ }^{41}$ Department for Constitutional Affairs, 'Further Findings: A continuing evaluation of the Civil Justice Reforms' (August 2002) <http://www.dca.gov.uk/civil/reform/ffreform.htm>.

42 id. paras. 3.8-3.12.

${ }^{43}$ id. paras. 3.3 and 3.5 .

44 id. para. 3.3 .

${ }^{45}$ BRTF, op. cit., n.3, at p.11.

${ }^{46}$ see, e.g., Armstrong, op. cit., n.40; G. Slapper, 'Why We Need More Lawyers' (2003) Law Society Gazette 100.43(15); F. Furedi, Courting Mistrust: The hidden growth of a culture of litigation in Britain. (London: Centre for Policy Studies, 1999); K. Qureshi, 'Opinion' The Lawyer 14 June 2004, 15 .

${ }^{47} \mathrm{cp}$. the regional bar as most mediation and arbitration specialists are based in London (The Lawyer, 21 May 2001, p.6).

${ }^{48}$ Furedi, op. cit., n.46, at pp.9-10.

${ }^{49}$ CEDR 'CEDR mediation figures reach all time high' (Press Release of 24 February 2004) <http://www.cedr.com/index.php?location=/news/archive/20040224.htm\&param=release>.

50 see, e.g., Lord Phillips MR quoted in Department for Constitutional Affairs, op. cit., n.41 at para. 3.24 .
} 
personal injury claims whether proceedings are issued or not. ${ }^{51}$ One problem with the Compensation Recovery Unit figures is that openly published figures only go back to 2000 .

\section{The Scarcity of Statistics}

Detailed and reliable statistics of a comprehensive scope are thus difficult to find (as noted variously by, e.g., Spier, Furedi and Morris). ${ }^{52}$ Williams describes the statistical evidence as "both incomplete and somewhat equivocal, counting as it does different things across different timescales." ${ }^{, 53}$ Industrial Tribunal figures going beyond 1985 are not available (a point noted by Burgess, Propper \& Wilson) ${ }^{54}$ and Civil court figures have not been included in the last two editions of Social Trends, the Office of National Statistics annual compilation of social and economic data from a wide range of government departments and other organisations, with the result that the analysis above starts with 1985 and stops at 2004. ${ }^{55}$ More up-to-date figures can usefully be drawn from the annual Judicial Statistics published by the Ministry of Justice but periodic changes to the information included there reduce the ability to derive lengthy time-series data. Care needs to be taken with the Judicial Statistics County Court figures as these have been amended in subsequent reports several times over the last few years (with totals changing by around 2-3\%). Care is also needed with the figures from the Employment Tribunal Service as, with new claims being included as the years go by, the layout of the statistics is not consistent. Indeed, the change in the 2001/02 layout is probably the reason why a House of Commons Research Paper contains a number of errors, e.g. recording an $113 \%$ increase in disability discrimination claims rather than a $90 \%$ increase (due to the race discrimination figures being used for 2001/02 and 2002/2003) and an $80 \%$ (rather than a 59\%) fall in claims for unfair dismissal on grounds of pregnancy when the figures for written pay statement claims were used for the last two years. ${ }^{56}$ With these caveats in mind, an analysis of Judicial Statistics and Employment Tribunal Service figures can provide a broader, yet detailed, insight.

\section{Judicial Statistics}

The general decline in Queen's Bench cases seen in Figure 3 above is reflected in breakdowns of both the number of claims issued by the Royal Courts of Justice and in the published weighted estimates of Queen's Bench Division judgments. Looking at both sets of figures helps acknowledge the argument that looking solely at judgments is of limited value as it ignores out of court settlements, ${ }^{57}$ however it should be noted

\footnotetext{
${ }^{51}$ Morris, op. cit., n.3 at p.356.

52 J. Spier, ed. The Limits of Liability: Keeping the Floodgates Shut (London, Kluwer Law International, 1996) 2; Furedi, op. cit. n.46 at pp.10-12; Morris, op. cit. n.3 at pp.355 and 357.

${ }^{53}$ Williams, op. cit. n.3 at p.504.

${ }^{54}$ Burgess, Propper \& Wilson, op. cit., n.37 at p.13.

${ }^{55} 2005$ is the most recent figure available from Social Trends but while the figures are ultimately derived from Judicial Statistics there appears to be a discrepancy in the 2005 figure. Cross-referencing the Social Trends figures with those in Judicial Statistics shows that the previous figures for County Court claims appear to include claims for recovery of land whereas the 2005 figure includes 'money' claims only.

${ }^{56}$ House of Commons Research Paper 03/87.

<http://www.parliament.uk/commons/lib/research/rp2003/rp03-087.pdf>.

${ }^{57}$ see, e.g. Lewis, Morris and Oliphant, op. cit., n.3 at p.87.
} 
that the 'judgments figures' (Figure 4) relate to the Queen's Bench as a whole (and are only available up until 2004) whereas the 'claims issued figures' (Figure 5) are taken solely from the Royal Courts of Justice. It is imperfect to use the Royal Courts of Justice as a proxy for all claims issued but, especially given the limited availability of statistics, it does add an element to the overall picture. Both sets of figures show personal injury claims contributing strongly to the decline and while there has been a marked increase in personal injury claims issued in 2006-2007 it is still around the level of the late 1990s. The figures for other types of cases either show a decline or

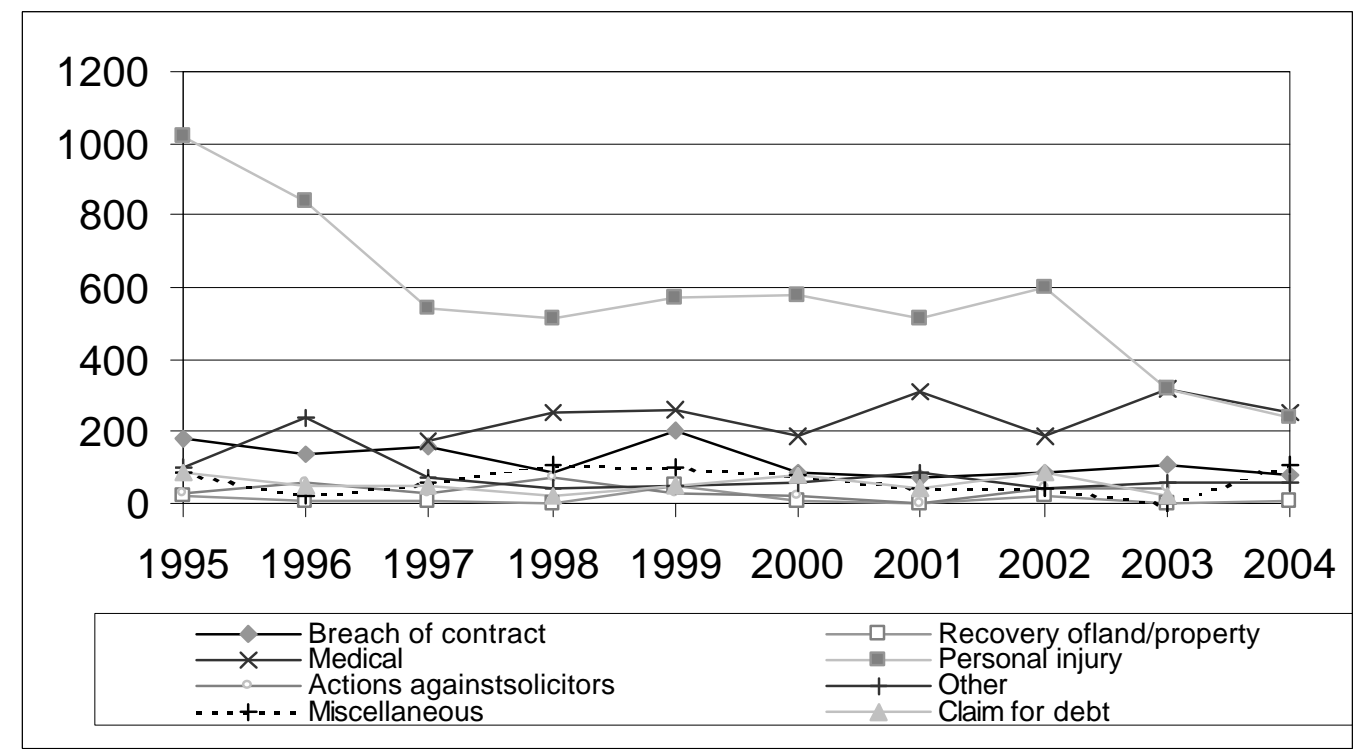

Figure 4 - Queen's Bench Division judgments by nature of claim (1995-2004)

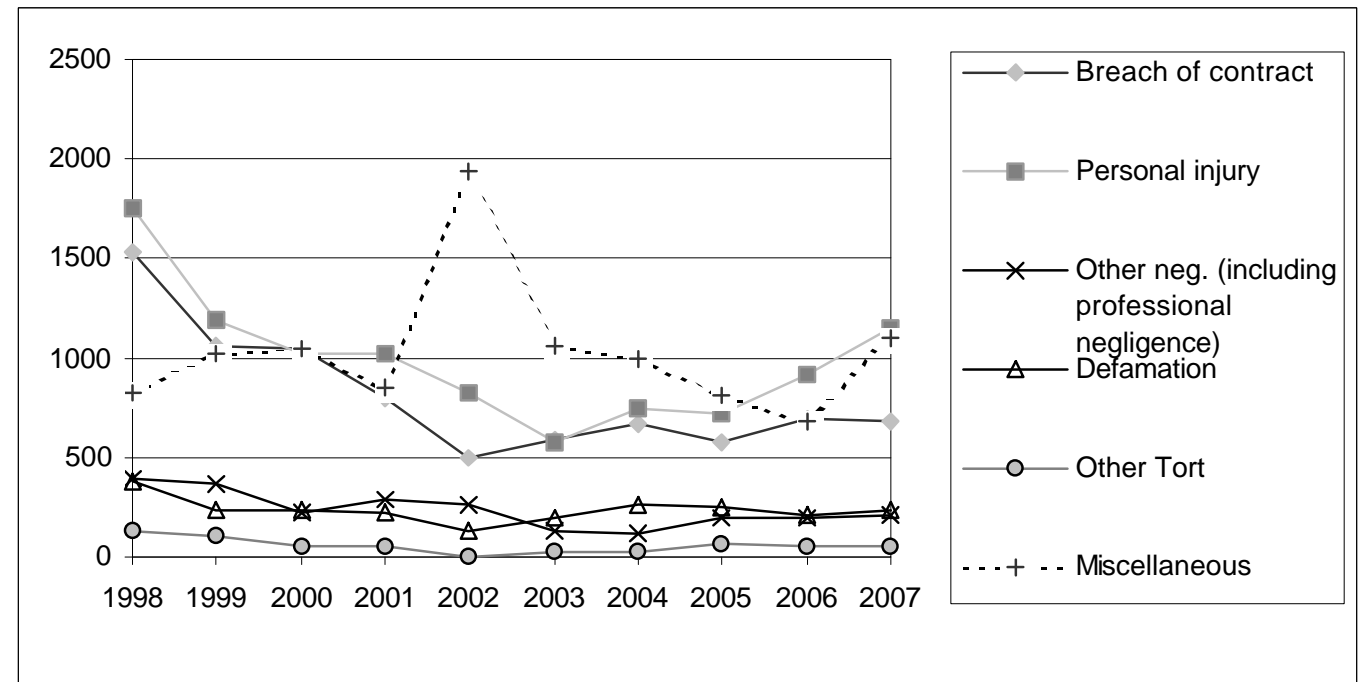

Figure 5 - Queen's Bench Division claims issued at the Royal Courts of Justice (19982007)

are broadly constant. The figures for claims for recovery of debt and recovery of land, both of which show very sharp declines, have not been included in Figure 5 as they are less relevant to the concept of a compensation culture and their inclusion would obscure the data for more relevant types of claims. While the ambit of the compensation culture can be quite wide, actions in Chancery are, generally speaking, not likely to be natural candidates and thus do not form part of the main analysis. It should, however, be noted that claimants may bring professional negligence claims which are clearly a target for compensation culture opprobrium - in either the Queen's 
Bench or in Chancery. It is thus worthy of brief note that such claims in Chancery have seen a steep decline. ${ }^{58}$

While the decline in county court actions set down for trial (including claims settled or struck out) has been driven by debt cases, personal injury cases displayed a downward trend, as Figure 6 shows, until the jurisdiction change in 1999 led to a levelling off. Although there has been, overall, a slight rise in 2003 and 2004 (the last two years for which data is available), the 1995 figure is still some $36 \%$ higher than the level in 2004.

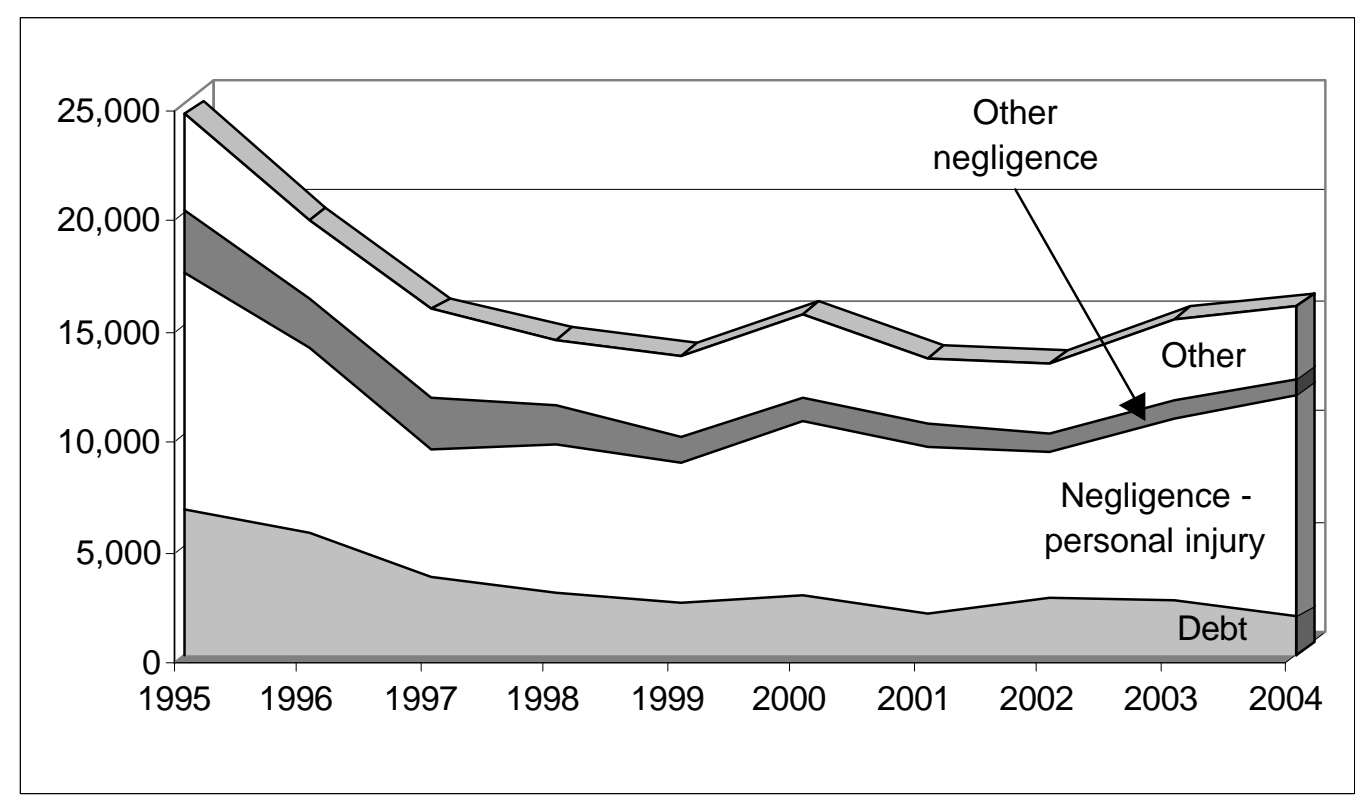

Figure 6 - County Court Trials, cumulative and by nature of claim, 1995-2004

As Armstrong points out, an increase in frivolous litigation would be reflected in the number of cases either struck out or settled. ${ }^{59}$ Taking personal injury claims as an example, as it is one of the few heads of claim common to the statistics for both courts, we can see that personal injury claims closely follow the total - and the trend in both courts is for an increase, rather than a decrease, in the percentage of claims that go to trial (Figure 7). ${ }^{60}$ Furthermore, any "surge" in stress based claims or, to quote Furedi $^{61}$, claims arising from "the acceptance of an ever-widening understanding of psychological distress", a common theme in the popular lament about the compensation culture, would mean that non-psychological personal injury claims would have had to have collapsed to enable the total to decline. ${ }^{62}$

\footnotetext{
${ }^{58}$ The average number of professional negligence claims and originating proceedings issued in London for the 3 year periods 1996-1998, 1999-2001, 2002-2004 and 2005-2007 is 667, 220.33, 173.67 and 56.67 (Judicial Statistics reports 1998-2007).

${ }^{59}$ Armstrong, op. cit., n. 40.

${ }^{60}$ The percentage of trials with judgment for the claimant has remained reasonably constant over the same period averaging around $74 \%$ in the $\mathrm{CC}$ and $76 \%$ in the QB.

${ }^{61}$ Furedi, op. cit., n.46, at p.17.

62 The Law Commission in Report No LC249 Liability for Psychiatric Illness considered that their proposals to remove some of the restrictions with regard to liability for psychiatric illness (e.g. removing proximity 'in time and space' and increasing the list of those deemed to have proximate 'ties of love and affection') would lead to an increase of just $10 \%$ in motor accident claims.
} 
This is the accepted version (post peer review) this article. It is made available here with due acknowledgement to the Journal of Law and Society, Cardiff University Law School and Blackwell Publishing. The article appears at (2010) Journal of Law and Society Vol. 37(4), 569-591 and the definitive online version is available at wileyonlinelibrary.com (http://onlinelibrary.wiley.com/doi/10.1111/j.1467-6478.2010.00522.x/pdf).

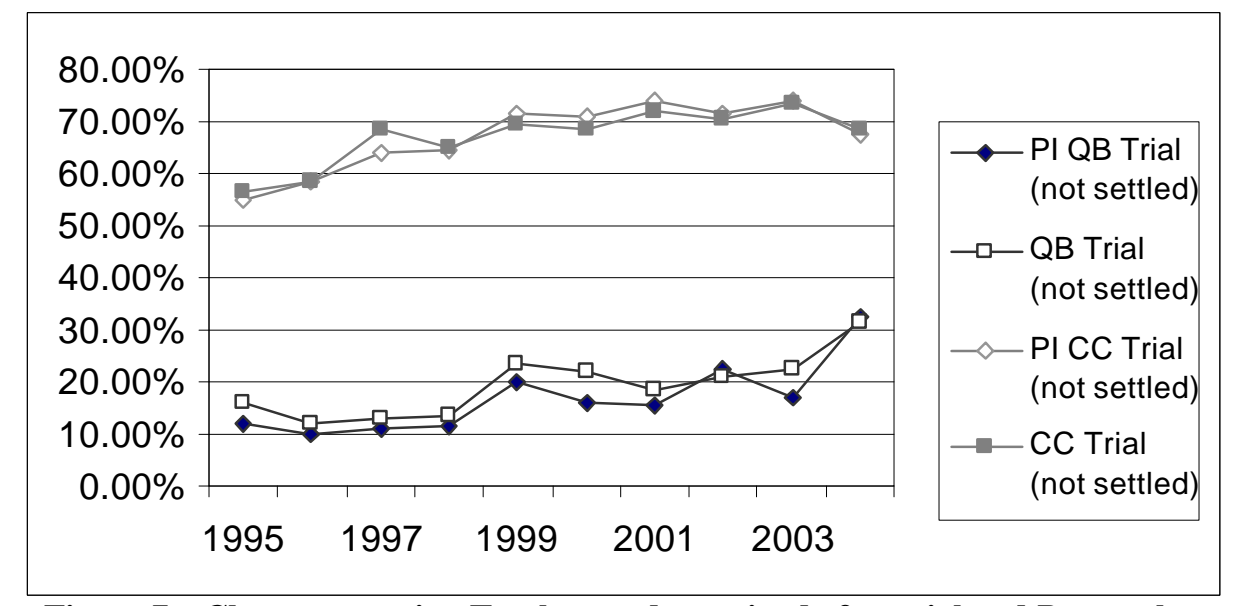

Figure 7 - Chart comparing Total cases determined after trial and Personal Injury cases determined after trial as a percentage of total cases (including those settled during trial, settled with consent order before trial, struck out or withdrawn) for the Queen's Bench and County Courts 1995-2004

\section{Defamation: a mixed picture}

Newspaper stories about defamation claims can also fuel the perception of a compensation culture, where people can win large rewards for seemingly little injury (being reputational rather than personal). It can be seen in Figure 5 above that, although volatile, defamation claims issued in the Royal Courts of Justice have certainly not increased. However, claims issued at the Royal Courts of Justice have fallen across all jurisdictions, and the decimation of debt and property claims along with a heavy fall in actions for breach of contract mean that defamation does now make a bigger contribution to the RCJ's total workload (in the mid-1990s it made up about $2 \%$ of claims but it now makes up on average 5\%-6\%). While the trend over the ten year period has been downward, claims in 2003/04 and 2004/05 increased by over $40 \%$ per year. This upward surge has not continued, despite fears that the emergence of new technologically-inspired claims in the information age and the half-million pound award by the Judicial Committee of the Privy Council in Gleaner v Abrahams would start an upward trend. ${ }^{63}$ The current level would appear to be a correction of the $72 \%$ fall between 1997 and 2002 .

An analysis of reported defamation cases, which is contrasted with claims issued in Figure 8, shows a steadier decline since 1999/2000, with the slight rise in 2003/2004 being attributed to post-9/11 allegations of terrorist links. ${ }^{64}$ These figures, drawn by the publishing house Sweet \& Maxwell from their Lawtel and Westlaw databases, are taken to indicate a general downturn, in contrast to the RCJ claims figures, and while this could point to more claims being settled and thus possibly not reported, it is salient to note that settlements that include a statement in open court may be reported (61\% of reported defamation cases in 2007/08 resulted in a statement in open court, up from $21 \%$ in 2004/05). ${ }^{65}$ Korieh Duodu suggests that the significant jump in cases in

\footnotetext{
${ }^{63}$ [2003] UKPC 55; for such fears see, e.g., "And now it's payback time: are we set for a return to the huge libel payouts of the 1980s?" The Independent, 12 August 2004 ("a landmark judgment by the Privy Council could open the floodgates for the rich, famous and litigious").

${ }^{64}$ Sweet \& Maxwell, 'Number of defamation court cases on the decline' (Press Release 26 August 2005) <http://www.sweetandmaxwell.co.uk/pressroom/2005/260805.html> Accessed: 17 September 2005.

${ }^{65}$ Sweet \& Maxwell, 'Proportion of defamation cases featuring celebrities continues to rise' (Press Release 9 October 2008) <http://www.sweetandmaxwell.co.uk/about-us/press-releases/091008.pdf> Accessed: 16 June 2009.
} 
1999/2000 could be due to the introduction of Conditional Fee Agreements for defamation cases. ${ }^{66}$ However, the leap in cases follows on from a leap in claims

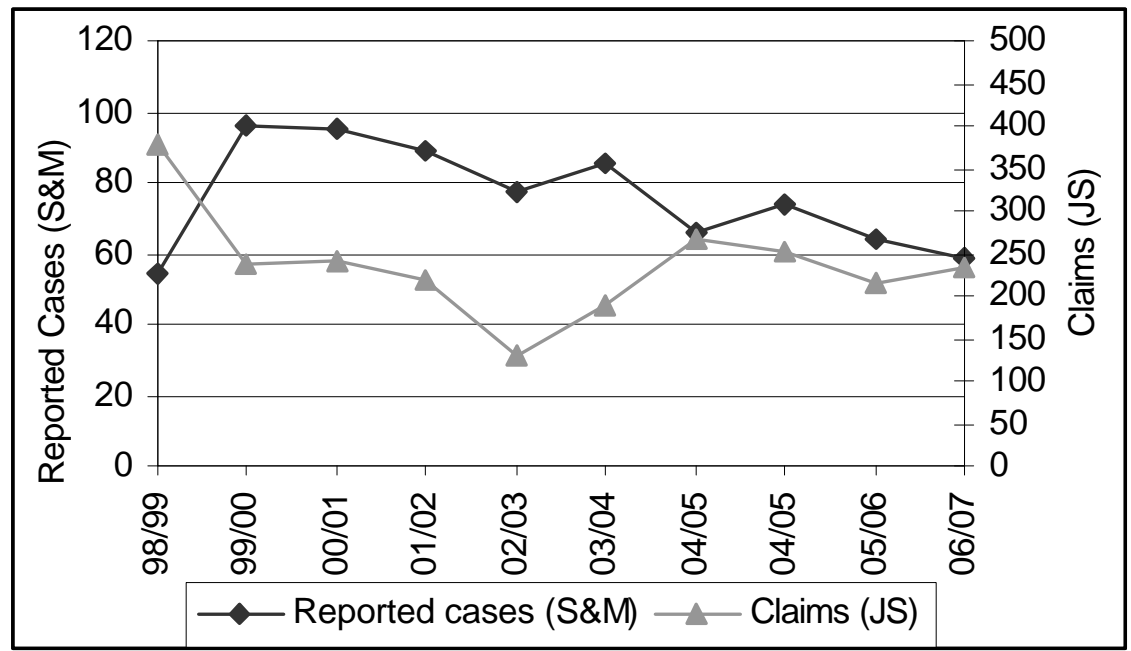

Figure 8 - Defamation: claims started in RCJ and cases reported in Westlaw/Lawtel 1998/99 - 2006/2007 compared

issued in 1997 and 1998 before the new-style CFAs were introduced and the decline a few years later is similarly mirrored (but the pattern for the last few years is currently unclear). ${ }^{67}$ Lewis, Morris \& Oliphant state that with regard to personal injury claims "[i]t must be emphasised that, contrary to popular belief, the introduction of conditional fee agreements ("CFAs") and the advent of widespread advertising by the claims industry have not increased the frequency of claims to any significant extent". 68 However, there is more scope for CFAs to impact on defamation claims as legal aid was not available for such claims unlike claims for personal injury. Indeed, the Ministry of Justice, while undertaking a consultation, proceeded on the basis that half of all defamation claims were funded by CFAs; though this is brought into doubt by Lord Justice Jackson's Review of Civil Litigation Costs where he cites Media Lawyers Association figures which show that, in 2008, only $17.5 \%$ of claims against their members were funded by a CFA. ${ }^{69}$ Furthermore, while the figures do not show a rise in claims, of greater concern is that the CFA regime, with its addition of a success fee on top of already high costs, has been used to blackmail defendants in defamation cases into settling early or being guarded as to what they publish. ${ }^{70}$ For example, as Zuckerman shows, in Musa King v Sunday Telegraph, the paper had the unenviable

\footnotetext{
66 in Sweet \& Maxwell, op. cit., n.64.

${ }^{67}$ The figures for the RCJ for 1996/97 and 1997/98 were 201 and 452.

${ }^{68}$ Lewis, Morris \& Oliphant, op. cit., n.3, at p.99. Furthermore, Lord Justice Jackson, in his preliminary report on costs, refers to a study by Fenn, Vencappa, O'Brien and Diacon (presented in written evidence to the House of Commons Select Committee on Constitutional Affairs in 2006) which found, with regard to employers' liability cases, that while costs had increased as a result of CFAs there was actually a lower propensity to litigate claims which are funded under CFAs with After-the-event insurance (Jackson, op. cit. n.33 at p. 96).

${ }^{69}$ Ministry of Justice, Conditional Fee Agreements in Publication Proceedings: Success Fees and After the Event Insurance (2007) (available at http://www.justice.gov.uk/consultations/docs/cp1607.pdf.) cited in Jackson, op. cit. n.33 at p. 342.

${ }^{70}$ Indeed, Ashby and Glasser contend that the costs of a defamation action are such that, with the addition of the success fee, the costs borne by the defendant may rise above the reasonable and proportionate level and thus be incompatible with the right to a fair trial. (cited in Zuckerman, 'Cost Capping Orders in CFA Cases Improve Costs Control but Raise Questions about the CFA Legislation and its Compatibility with Art.6 of the European Convention on Human Rights' (2005) 24 Civil Justice Quarterly 1, 12.
} 
choice of (i) settling for $£ 150,000$, (ii) losing and being liable for over $£ 1$ million or (iii) winning but still be landed with a legal bill of $£ 400,000 .^{71}$ This is more to do with the 'chilling effect' on free speech than a 'compensation culture' but these concerns led to the Conditional Fee Agreements (Amendment) Order 2010 being laid before Parliament in March 2010 which would have capped the maximum success fee in defamation cases to $10 \%$. Had this Order, which ran into widespread criticism in Parliament and elsewhere (not least for the arbitrary nature of the figure), not been abandoned $^{72}$, then if there is any increase in claims due to CFAs, that would have been set to diminish. Lord Justice Jackson, in his wide-ranging report on civil costs, has also recommended a change whereby success fees and after-the-event insurance would no longer be recoverable by the claimant (with poorer claimants offered some protection through the introduction of a regime of qualified one way costs shifting). ${ }^{73}$ It is currently unclear what reform will take place, but there is a very high prospect of a comprehensive and transformative Defamation Act, appearing within the next few years. $^{74}$

Employment: Onwards and Upwards

Of the three courts featured in Figure 3, it is only the employment tribunals that display an upward trend. Again, there are some difficulties with the statistics with, for example, the Employment Tribunal Service reporting only the total, or multi, jurisdiction figure from 2004. Claims may be brought to employment tribunals under more than one jurisdiction, for example unfair dismissal, breach of contract and discrimination, and longer term studies have tended to use the formerly published main jurisdiction (that is the principal type of claim when first received). The number of claims (which is still published but which is no longer broken down) is typically around $60 \%$ of the multi-jurisdiction figure, that is to say that there are around oneand-a-half to two jurisdictions per claim. ${ }^{75}$

Drawing on figures from the study by Burgess, Propper \& Wilson as well as ETS figures, it can be seen in Figure 9 that discrimination is making up an increasing part of the tribunals' workload - from between $5-10 \%$ in the late 1980 s to around $20 \%$ in the early 2000s. Unfair dismissal applications have been generally stable since 1991, a point noted by Burgess, Propper \& Wilson. ${ }^{76}$ The two peaks in discrimination, between 1994 and 1996 and in 2000/01, are due to an abnormally large number of part-time worker pension cases ${ }^{77}$ and the uplift in 2003 is attributable to the surge in

${ }^{71}$ [2004] EWCA Civ.613 (affg EWHC 1312); Zuckerman, ibid. at p 5

${ }^{72}$ See, e.g., http://lsemediapal.blogspot.com/2010/03/update-on-10-success-fee-order-commons.html for a summary of the troubled existence of the draft Conditional Fee Agreements (Amendment) Order 2010.

73 Jackson L.J., 'Review of Civil Litigation Costs: Final Report' (December 2009) London: The Stationery Office, pp. 324-327 < http://www.judiciary.gov.uk/about_judiciary/cost-review/jan2010/ final-report-140110.pdf> [Accessed July 2, 2010].

${ }^{74}$ The prospect of a comprehensive defamation bill was announced, in an unusually certain way, by Lord McNally, Minister of State, during the Second Reading of Lord Lester's more limited Defamation Bill (Hansard HL Deb. vol. 720, cols 477 and 480 (July, 9, 2010)).

75 The total number of claims as a percentage of the total of the multi-jurisdiction breakdown of claims is: $(98 / 99) 61.8 \%$; (99/00) $58.8 \%$; (00/01) 59.8\%; (01/02) 57.8\%; (02/03) 57.2\%2; (03/04) 58.3\%; (04/05) 55.2\%; (05/06) 57.1\%; (06/07) 55.6\%; (07/08) 63.7\%.

${ }^{76}$ Burgess, Propper \& Wilson, op. cit., n.37, at p.3.

${ }^{77}$ Following the ECJ cases of Vroege v NCIV Instituut voor Volkshuisvesting BV (Case C-57/93) and Fisscher v Voorhuis Hengelo BV (Case C-128/93) [1995] ICR 635 and the HL decision in Preston \& 
'dress code' cases following the tribunal's decision, in Department of Work \& Pensions $v$ Thompson, that requiring men to wear a collar and tie was discriminatory. In the few months before the tribunal's decision was reversed by the Employment Appeals Tribunal in the November of 2003, thousands of Mr Thompson's colleagues had begun actions. ${ }^{78}$ Even if these instances are discounted, the trend is still upward although not as much as the trend in other claims (which encompasses an increasing number of types of complaint: the tribunals' jurisdiction increasing from over fifty in $1999 / 2000$ to over seventy in 2004/2005). ${ }^{79}$

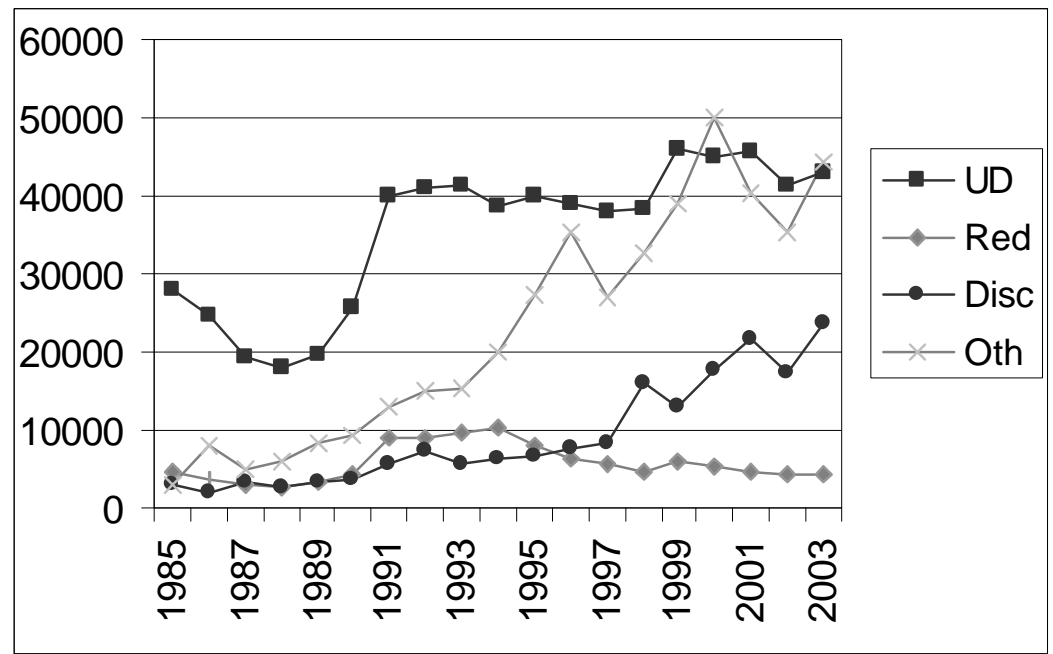

Figure 9 - Applications to Industrial/Employment Tribunals 1985 - 2003 by main jurisdiction

An analysis of the figures for the past ten years (Figure 10), further shows the increased trend in discrimination claims (although the absolute figures have changed due to the switch to multi-jurisdiction figures, a similar trend is evident in the overlapping years). The very large spike in other claims in 2007/2008 is in large part due to Working Time Directive claims that have been resubmitted a number of times. The recent very large spike in discrimination claims is due in part to ongoing Local Authority equal pay claims which should by now be coming to a conclusion. There has, nevertheless, been a steep rise in discrimination claims over the last decade, not least with the establishment of disability discrimination ${ }^{80}$ and the introduction of actions for discrimination on the grounds of religion or belief and on the grounds of sexual orientation in 2003 and on the grounds of age in 2006. This tripling of the heads of claim has over the years since their introduction contributed a $10 \%-25 \%$ increase in discrimination claims (with age claims set to increase that further). ${ }^{81}$

Ors $v$ Wolverhampton Healthcare NHS Trust and Others (No 2) [2001] 2 AC 455; such cases made up just under $50 \%$ of the live applications outstanding each year for much of the first half of this decade.

${ }_{78}$ Department of Work and Pensions $v$ Thompson [2004] IRLR 348; the peaks in Other claims in 2000 and 2003 reflect the introduction of the Part-time workers regulations (claims in subsequent years under which have been less than a twentieth of the 2000 figure) and a large multiple case under the Working Time Regulations heard at Watford (Employment Tribunal Service, Annual Report And Accounts 2004, p.23).

${ }^{79}$ Employment Tribunal Service Annual Reports 1999/00 - 2004/2005.

${ }^{80}$ Although introduced by the Disability Discrimination Act 1996, as with the subsequent legislation, it takes a few years for the flow of cases to really start.

${ }^{81}$ The increases due to the new jurisdictions were $199813.21 \% ; 199918.55 \% ; 20008.91 \% ; 2001$ 15.68\%; 2002 21.24\%; 2003 18.42\%; 2004 19.39\%; 2005 13.30\%; 2006 9.12\%; 2007 9.70\%. The low values in 2006 and 2007 correspond to the peaks caused by the mass Local Authority Equal Pay claims. 
While the irregular peaks caused by particular issues such as those mentioned above are much greater than this, these new heads of claim contribute a steady accretion to the level of discrimination claims.

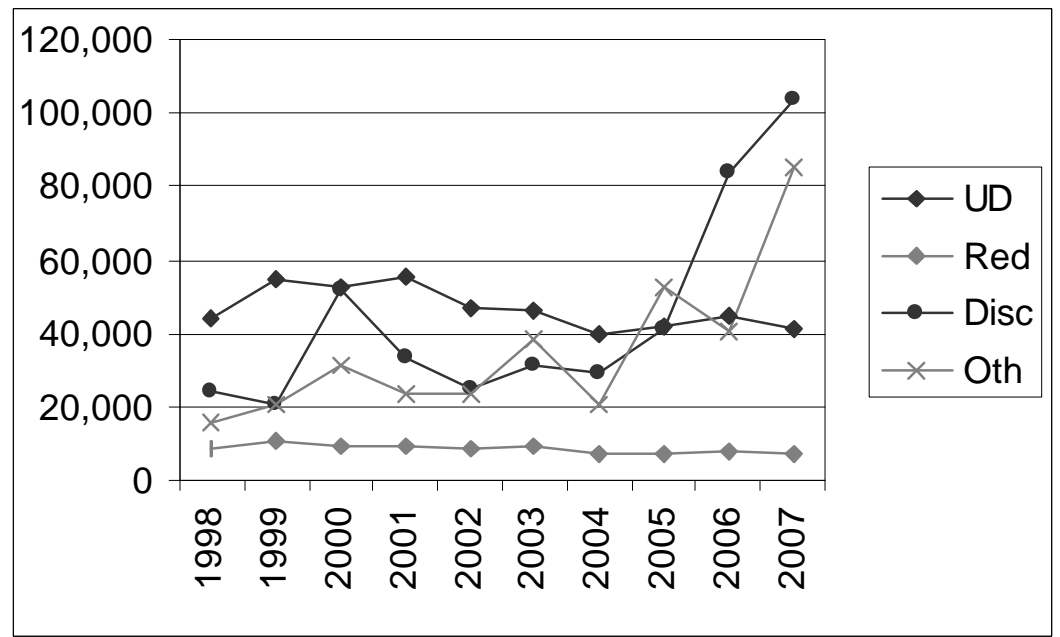

Figure 10 - Applications to Employment Tribunals 1998 - 2007 (multijurisdiction figures)

Not only are discrimination claims increasing, but the compensation awarded is also going up. The Law Society, in evidence to the Trade and Industry Select Committee concerning removing the limit on the unfair dismissal compensatory award, noted that the median award in sex and race cases had increased by little more than $£ 1,000$ following the decision in Marshall $v$ Southampton and SW Hants AHA (No.2) [1993] ICR 893, ECJ which saw the removal of the cap on compensation claims for discrimination (which had been set at $£ 6,250$ ). ${ }^{82}$ However, in the years that have followed, the median awards for both sex and race discrimination have more than doubled and the disability median has seen a recent sharp rise (Figure 11). While the figures are still a mere fraction of the awards in the US - being measured in the low

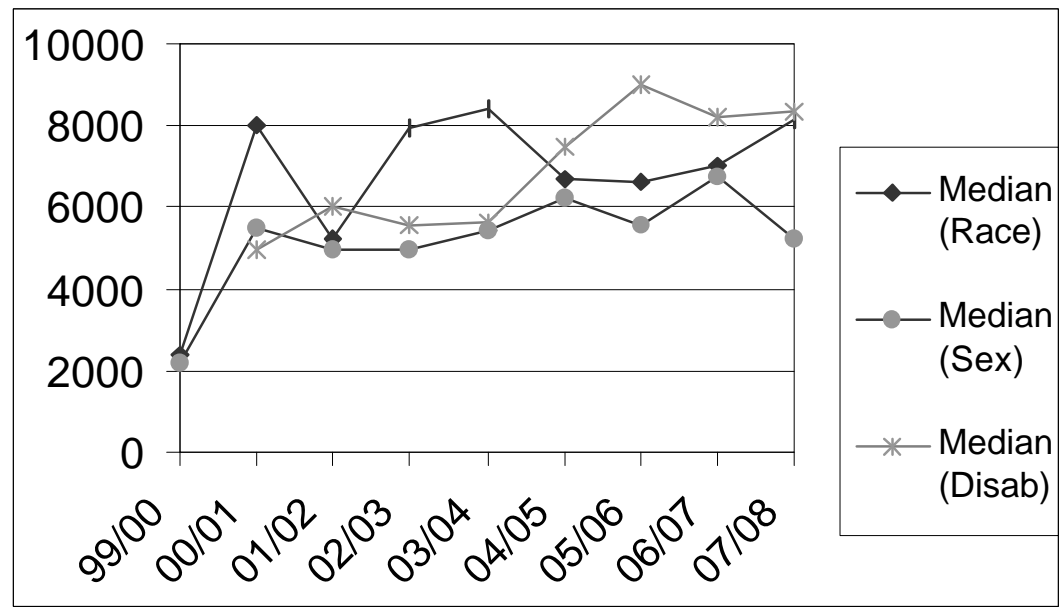

Figure 11 - Median Awards in Race, Sex and Disability Discrimination cases 1999/2000 - 2007/2008

The raw figures show an increase from 3,151 in 1998 to 10,073 in 2007 (the first full year of the Age Regulations).

${ }^{82}$ Law Society, 'Memorandum submitted by the Law Society to Select Committee on Trade and Industry' <http://www.publications.parliament.uk/pa/ cm199798/cmselect/cmtrdind/980/ 8072118.htm> 
tens-of-thousands rather than in hundreds-of-thousands ${ }^{83}$ - such increases are given added significance by the finding of Burgess, Propper \& Wilson that the amount of money won is, in contrast to other tribunal claims, significantly associated with the number of cases brought. However, if one looks at the average awards over the last nine years (Figure 12) - during which time the compensation culture has been most in the headlines - any increase has been small over the period as a whole.

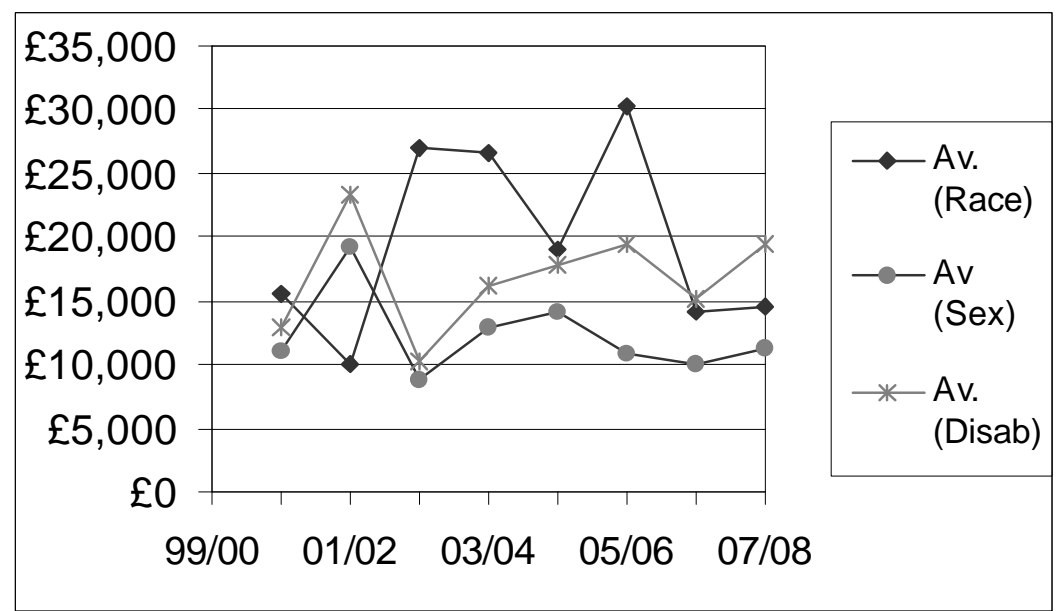

Figure 12 - Average Awards in Race, Sex and Disability Discrimination cases 2000/2001 - 2007/2008

\section{Conclusion}

The Press and some politicians would lead us to believe that we, in the UK, are in the midst of a compensation culture and facing the prospect of slipping down the slope toward American-style litigiousness. ${ }^{84}$ If we take the concept of a "compensation culture' as one which involves an increase in claims over recent times caused by people's increased willingness to sue, then this is disproved by recent studies, with regard to personal injuries, which show that claims have actually fallen during the period in which the 'compensation culture' has attracted much popular, and derisive, debate. This article has sought to extend the analysis to other areas of law. It can be

\footnotetext{
${ }^{83}$ Taking 2001 as an example, the median award in the US for employment discrimination was $\$ 166,000$ and the average $\$ 615,247$ (statistics extracted from T.H. Cohen \& S.K. Smith, Civil Trial Cases and Verdicts in Large Counties 2001 (Bureau of Justice Statistics Bulletin, 2004). Furthermore, the US case of Weeks v Baker \& McKenzie saw an award which "was over twice the total amount awarded to all successful claimants of sex discrimination in Britain for 1998" (J.M. Kelly \& A. Sinclair, 'Sexual harassment of employees by customers and other third parties: American and British views' (2000) 31 Texas Tech Law Review 807, at 865; cf. J.M. Kelly \& B. Watt, 'Damages in Sex Harassment Cases: A Comparative Study of American, Canadian, and British Law' (1996) 16 New York Law School Journal of International and Comparative Law 79, at pp.98-105).

${ }^{84}$ This concern over increasing liability is by no means limited to the UK. In Spier, ed., op. cit., n.51, a marked trend in Austrian law of increasingly allowing injured parties to pass on their damage is noted, for example, along with the potential for "delictual inflation" in Greek tort law and the "extension de la notion de faute, multiplication de cas de responsabilité sans faute... [et] générosité croissante des tribunaux pour l'indemnisation de certains dommages" ("the extension of fault and strict liability and the increasing generosity of tribunals with regard to some types of harm') in France (p.2). It is also a big topic in the US itself with much written about it on both sides of the debate, e.g., Kritzer, op. cit., n.2, Galanter, op. cit., n.10, Dobbs in Spier ed, op. cit., n.52 and J.T. Nockleby \& S. Curreri, '100 Years of Conflict: The Past and Future of "Tort Retrenchment," (2005) 38 Loyola of Los Angeles Law Review 1021. Belgium, by contrast, "is apparently not inclined to find ways to keep the floodgates shut" (Spier, ed, op. cit., n.51, at p.3).
} 
seen that far from spiralling upwards, there has been a downward trend over the past two decades with the exception of employment tribunal claims. The increase in employment tribunal claims is not due to the exploitation of the tort system by greedy claimants and lawyers out for all they can get, but through the creation of statutory rights designed to protect people in the workplace, such as the introduction of the prohibition of discrimination on the grounds of religion, sexual orientation and age. A common difficulty in the studies in this area has been the long-term availability and consistency of statistics.

In order better to redress the popular misconception, more attention should be paid both to the statistics that are available, which this article has sought to do, and to the collection and publication of court data. Such data can be used to highlight problems as they arise as well as give the lie to media hype. The compensation culture cliché may not be a reality, but if it discourages people from pursuing truly legitimate claims - or undertaking valuable activities - then it is, nevertheless, a very real cause for concern. 